\title{
INCREASING THE EFFICIENCY OF PROCUREMENT PROCESSES AS A RESULT OF IMPLEMENTING CATEGORY MANAGEMENT
}

\author{
Oksana Yu. Kirillova \\ Plekhanov Russian University of Economics (REU), Moscow, Russian Federation
}

Olga V. Lantsova

JSC “Concern Rosenergoatom”, Plekhanov Russian University of Economics, Moscow, Russian Federation

\begin{abstract}
The contract system requires the development and adoption of management decisions to improve and optimize in order to increase the efficiency of budget expenditures at all different levels and stimulate the development of the real sector of economics. The subject of the study is the innovative approach based on the introduction of management by category. The article substantiates the need and shows the advantages of introducing category management in the procurement system of companies, describes its methodology, shows the process of developing and implementing the category strategy, including the following main stages: planning needs for the subject of procurement with the allocation of the category; forming a document with basic data; market analysis; strategy development, its implementation and monitoring; approaches to calculating the expected and actual effect of implementing this strategy; results of approbation of the management approach to the categories on the example of centralized procurement of vehicles. Restructuring the management system from the standpoint of category management is the most relevant for large companies with an extensive regional network and a large number of internal customers of goods, works and services.
\end{abstract} efficiency.

Key words: category, managing categories, category management, procurement management, procurement

Citation. Kirillova O.Yu., Lantsova O.V. Increasing the Efficiency of Procurement Processes as a Result of Implementing Category Management. Journal of Volgograd State University. Economics, 2019, vol. 21, no. 3, pp. 129-142. (in Russian). DOI: https://doi.org/10.15688/ek.jvolsu.2019.3.12

\section{ПОВЫШЕНИЕ ЭФФЕКТИВНОСТИ ЗАКУПОК КАК РЕЗУЛЬТАТ ВНЕДРЕНИЯ КАТЕГОРИЙНОГО МЕНЕДЖМЕНТА}

\section{Оксана Юрьевна Кириллова}

Российский экономический университет им. Г.В. Плеханова, г. Москва, Российская Федерация

\section{Ольга Валерьевна Ланцова}

АО «Концерн Росэнергоатом», г. Москва, Российская Федерация

Российский экономический университет им. Г.В. Плеханова, г. Москва, Российская Федерация

Аннотация. Контрактная система требует разработки и принятия управленческих решений по усовершенствованию и оптимизации в целях повышения эффективности расходов бюджетов всех уровней и стимулирования развития реального сектора экономики. Предметом исследования выступил инновационный подход, основанный на внедрении управления по категориям. В статье обоснована необходимость и обозначены преимущества внедрения в системы закупочной деятельности компаний категорийного менеджмента, описана его методология, а также показан процесс разработки и реализации категорийной стратегии, вклю- 
чающий следующие основные этапы: планирование потребности по предмету закупки с выделением категории; формирование документа с основными данными; анализ рынка; собственно разработка стратегии, ее реализация и контроль внедрения. Приводятся подходы к расчету ожидаемого и фактического эффекта от внедрения данной стратегии, представлены результаты апробации подхода управления по категориям на примере централизованной закупки автотранспортных средств. Реструктуризация системы управления с позиций категорийного менеджмента наиболее актуальна для крупных компаний, имеющих разветвленную региональную сеть и большое количество внутренних заказчиков товаров, работ и услуг.

Ключевые слова: категория, управление категориями, категорийный менеджмент, управление закупками, эффективность закупок.

Цитирование. Кириллова О. Ю., Ланцова О. В. Повышение эффективности закупок как результат внедрения категорийного менеджмента // Вестник Волгоградского государственного университета. Экономика. -2019. - Т. 21, № 3. - C. 129-142. - DOI: https://doi.org/10.15688/ek.jvolsu.2019.3.12

\section{Введение}

В сфере управления закупками происходят активные процессы реформирования областей государственного регулирования. Вопросы формирования и осуществления закупок для целей обеспечения государственных и муниципальных нужд тесно связаны с современной экономической политикой, управлением государственными и муниципальными финансами. Контрактная система требует разработки и принятия управленческих решений по усовершенствованию и оптимизации в целях повышения эффективности расходов бюджетов всех уровней и стимулирования развития реального сектора экономики.

В условиях сильно насыщенного товарами рынка у потребителей появляются трудности, связанные с выбором необходимых товаров. Это выдвигает задачу формирования оптимального ассортимента товаров, который не может возникнуть без тщательной проработки возможностей рынка. На современном этапе развития рыночной экономики инновационные подходы базируются на применении концепции и методологии категорийного менеджмента.

В сфере закупок категорийный менеджмент - это не только научная концепция, но и практический системный подход к управлению их эффективностью, при котором крупные федеральные участники рынка могут добиться неоспоримых преимуществ по сравнению с региональными игроками. Данная тематика является актуальной, так как каждая организация стремится осуществить закупки со снижением затрат при соблюдении требований к качеству и срокам поставки заку- паемых ресурсов, работ или услуг, поэтому существует необходимость выбора оптимального способа закупки, поставки и получения результатов. Категорийное управление ориентировано наибольший эффект в закупках, который достигается с помощью профессионального учета влияния закупаемой продукции, ее ассортимента, качества, рисков, отсутствия и пр. на производственные результаты деятельности компании в целом, а также на управление развитием поставщиков [Вавилина и др., 2016].

Значение государственных (муниципальных) и корпоративных закупок в отечественной экономике сложно переоценить. Так, согласно данным единой информационной системы (далее - ЕИС), в 2017 г. было размещено более 3,16 млн извещений о закупках на сумму более 7 трлн руб. по Федеральному закону от 05.04.2013 № 44-Ф3 «О контрактной системе в сфере закупок товаров, работ, услуг для обеспечения государственных и муниципальных нужд». Данные по закупкам отдельными видами юридических лиц еще более внушительны. Так, в 2017 г. по Федеральному закону от 18.07.2011 № 223-Ф3 «О закупках товаров, работ, услуг отдельными видами юридических лиц» было размещено более 1,3 млн извещений, общий объем которых превысил 27 трлн рублей. Таким образом, объем рынка государственных (муниципальных) и корпоративных закупок превысил треть валового внутреннего продукта. В силу этого российская система закупок способна оказывать существенное влияние на макроэкономические показатели государства и на решение ключевых задач экономической политики, таких как развитие малого и среднего бизнеса, 
стимулирование импортозамещения, государственная поддержка инноваций. В этой связи совершенствование закупочной системы (повышение ее эффективности, снижение издержек, рост конкуренции и минимизация коррупциогенных рисков) - императив развития всей отечественной экономики.

Заказчики при закупке товаров, работ и услуг, действующие на основании Федерального закона № 223-Ф3, руководствуются следующими принципами:

1) информационная открытость закупки;

2) равноправие, справедливость, отсутствие дискриминации и необоснованных ограничений конкуренции по отношению к участникам закупки;

3) целевое и экономически эффективное расходование денежных средств на приобретение товаров, работ, услуг (с учетом при необходимости стоимости жизненного цикла закупаемой продукции) и реализация мер, направленных на сокращение издержек заказчика;

4) отсутствие ограничения допуска к участию в закупке путем установления неизменяемых требований к участникам закупки.

Своевременное и бесперебойное снабжение товарами, сырьем, комплектующими, расходными материалами и инструментами выступает одним из существенных факторов, оказывающих непосредственное влияние на эффективность работы торговой или производственной компании и достижение ее стратегических целей. Профессионально организованный процесс снабжения должен обеспечивать не только эффективность, но и высокие показатели оборачиваемости запасов, снижение себестоимости закупок, а также другие показатели.

Крах советской распределительной системы финансирования, попытки перехода от планово-директивной системы управления экономикой к рыночной заставили собственников предприятий и топ-менеджеров обратиться к зарубежному опыту и попытаться трансформировать систему снабжения в компаниях. Понятно, что для разных типов торговли или производства, разных масштабов бизнеса существуют различные системы построения закупочной деятельности и материально-технического обеспе- чения. За рубежом в многономенклатурной торговле, а также в серийных производствах сложных изделий с использованием большой номенклатуры сырья, материалов и комплектующих широкое применение получил так называемый категорийный менеджмент. Этот термин впервые был введен в практику организации закупок в начале 1990-х гг. компанией «Procter\&Gamble», a основателем категорийного менеджмента считается профессор Калифорнийского университета, американец австралийского происхождения Брайан Ф. Харрис. В России категорийный менеджмент пока не получил широкого применения, но есть успешные попытки его внедрения в крупных производственных компаниях и компаниях, работающих по западным бизнес-процессам [Ломтев, 2016].

Категорийный менеджмент - деятельность по управлению ассортиментом товаров внутри организации, предназначенная для упорядочения и оптимизации всех операций, которые относятся к определенной товарной категории.

Категория товаров - группа однородной продукции, объединенная общим признаком и/ или предназначенная для использования с одинаковой конечной целью, обладающая при этом характерным для данной категории набором рыночных предложений.

Категория работ (услуг) - группа работ (услуг) с одинаковым конечным результатом, одинаковым набором требуемых для выполнения ресурсов, обладающая при этом характерным для данной категории набором рыночных предложений [Приказ от 18.11.2016 № 9_1496-П ...].

Категорийная стратегия - план действий для эффективного управления закупками товаров, выполнением работ или оказанием услуг со стороны заказчика, взаимодействием с поставщиками в рамках категории.

Развитие торговли происходит путем совершенствования применяемых форм, средств и методов. При этом некогда перспективные средства и методы со временем снижают свою эффективность или в ряде случаев вообе ее утрачивают, поэтому для обеспечения конкурентоспособности торговые организации вынуждены разрабатывать и вне- 
дрять новые методы управления, которые затем заимствуют и развивают с учетом своих особенностей другие организации. К числу таких методов относится управление товарными категориями.

Система категорийного менеджмента решает проблему противоречия между закупками и продажами в компании, так как эти процессы часто конфликтуют между собой, преследуя разные цели. Данная система подразумевает осуществление общего процесса управления товаром и стратегическое развитие ассортимента.

Спектр функций категорийного менеджера гораздо шире, чем у менеджера по закупкам: помимо выявления необходимости закупки товаров, ресурсов или услуг конкретного вида, он также определяет политику ценообразования, выстраивает логистическую цепочку перемещения товаров, принимает решение о расширении или сокращении их ассортимента. Более того, он определяет стратегию закупок по компании в целом, то есть должен мыслить опережающим образом, хорошо разбираться в потребностях бизнес-процессов компании. Категорийный менеджер отвечает за весь цикл закупки и использования товара. Это становится особенно актуальным, когда компания имеет множественные подразделения и филиалы.

Внедрение категорийного менеджмента подразумевает сложный процесс изменений, включающий большое количество методологических и организационных процедур. В первую очередь проводятся работы по централизации всей закупочной деятельности, нормированию, пересмотру норм материальных запасов, стандартизации и унификации потребностей компании, оптимизации виртуального обмена товарными запасами между подразделениями. Параллельно устраняются причины формирования невостребованных запасов и возникновения потребности в аварийных и внеплановых закупках.

Внедрение категорийного менеджмента меняет стратегию закупок. Первоочередное значение приобретает оценка затрат в цепи поставок. Для этого предварительно определяются способы закупок, в системе управления акцент делается на контракты и контрактные обязательства, проводится сертифика- ция поставщиков, внедряются новые подходы к ценообразованию и договорной работе.

Таким образом, категорийный менеджмент становится эффективным инструментом управления цепочкой поставок, в каждом звене которой применяется наиболее прогрессивная методика организации. Формирование системы категорийного менеджмента с учетом современных методов управления позволяет получить целый ряд преимуществ для всех участников. К ним можно отнести следующие:

- повышение эффективности и производительности труда в процессе закупок, снижение товарных запасов и повышение их оборачиваемости, оптимизация документооборота, что приводит к снижению общих издержек в цепи поставок;

- повышение качества сервиса поставок за счет сокращения сроков выполнения заказа, применения элементов систем типа «Канбан», непрерывного мониторинга поставки, полного и своевременного удовлетворения нужд внутренних и внешних потребителей;

- повышение эффективности управленческих решений за счет обеспечения прозрачности всех процессов;

- рост вовлеченности сотрудников в бизнес-процессы компании;

- рост адаптивности к изменениям внешней среды.

В рамках категорийного менеджмента кардинальным образом меняется система закупок, в том числе процесс определения потребности в закупаемой категории материалов. Управление категориями позволяет преодолеть разрозненность в закупках и повысить их результативность. При этом оптимизируется сама процедура определения и планирования потребности. Переход от излишне регламентированной, бюрократизированной, пошаговой модели закупочного процесса к стратегическому управлению категориями дает быстрый результат. Экономический эффект в диапазоне одного-двух лет, достигнутый российскими компаниями, внедрившими систему категорийного менеджмента, достигает сотен миллионов рублей [От стратегии ...].

Составляющие общей стратегии закупок представлены на рисунке 1. 


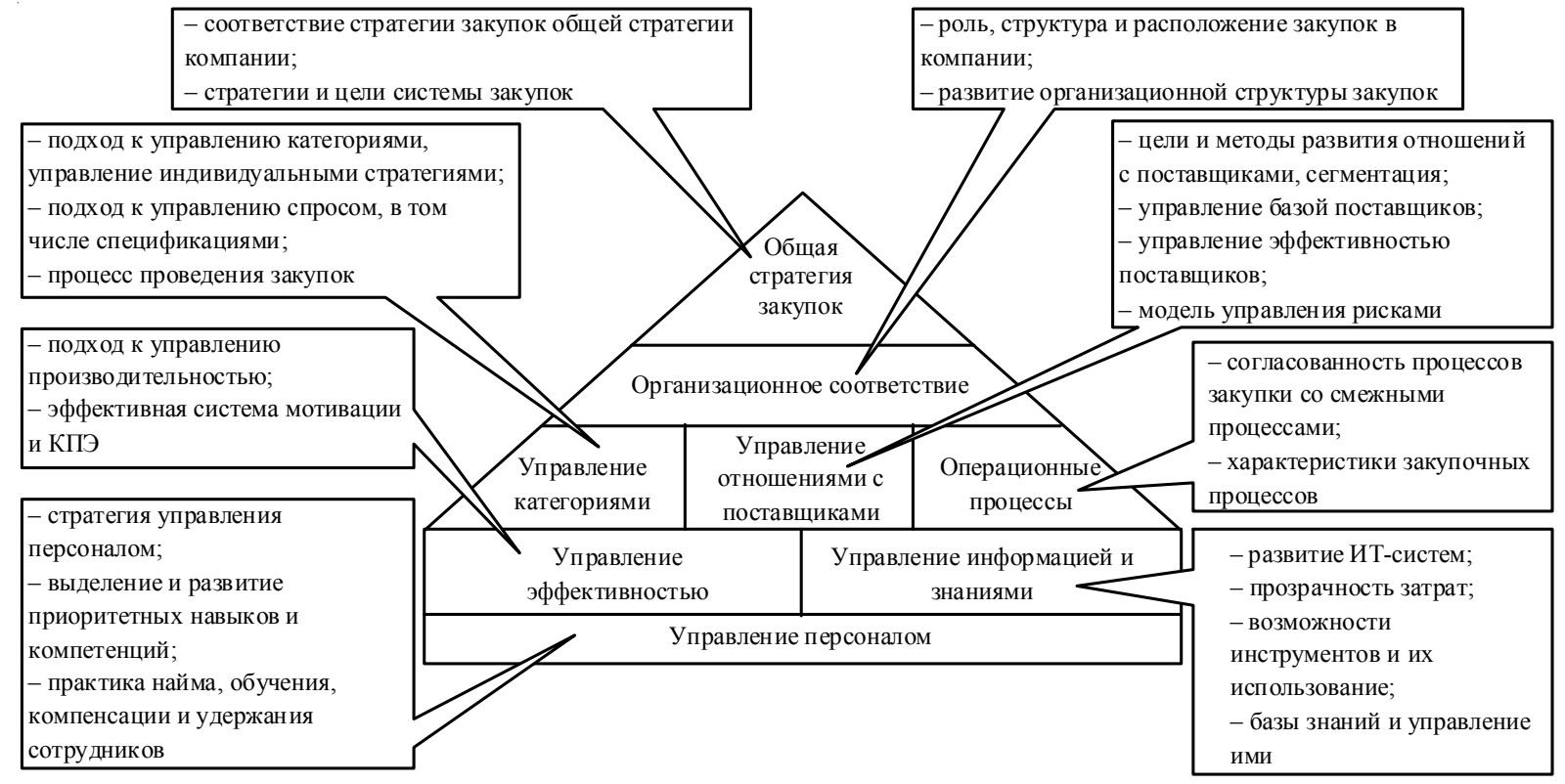

Рис. 1. Содержание общей стратегии закупок

Примечание. Составлено авторами по: [Совершенствование ...].

\section{Методика}

Для управления категориями используется методический подход, состоящий из 6 шагов: 1) планирование потребности и выделение категорий; 2) формирование документа, включающего в себя основные данные по категории закупки; 3) анализ рынка; 4) разработка стратегии; 5) реализация стратегии; 6) контроль внедрения (рис. 2) [Единые отраслевые ...].

1. Планирование потребности и выделение категорий.

Первый шаг в процессе управления категориями - планирование потребности при формировании годовых и среднесрочных планов и выделение категорий. Основная цель сформировать перечень требуемой номенклатуры ресурсов, работ и услуг, из которого выделяются категории.

Выделение позиций работ или услуг, имеющих одинаковый классификационный номер, позволяет сгруппировать их в одну категорию.

2. Формирование документа, включающего в себя основные данные по категории закупки.

Сбор данных по истории закупок состоит в получении информации об изготовителях, поставщиках, уровне цен, конкуренции поставщиков в рамках категории.

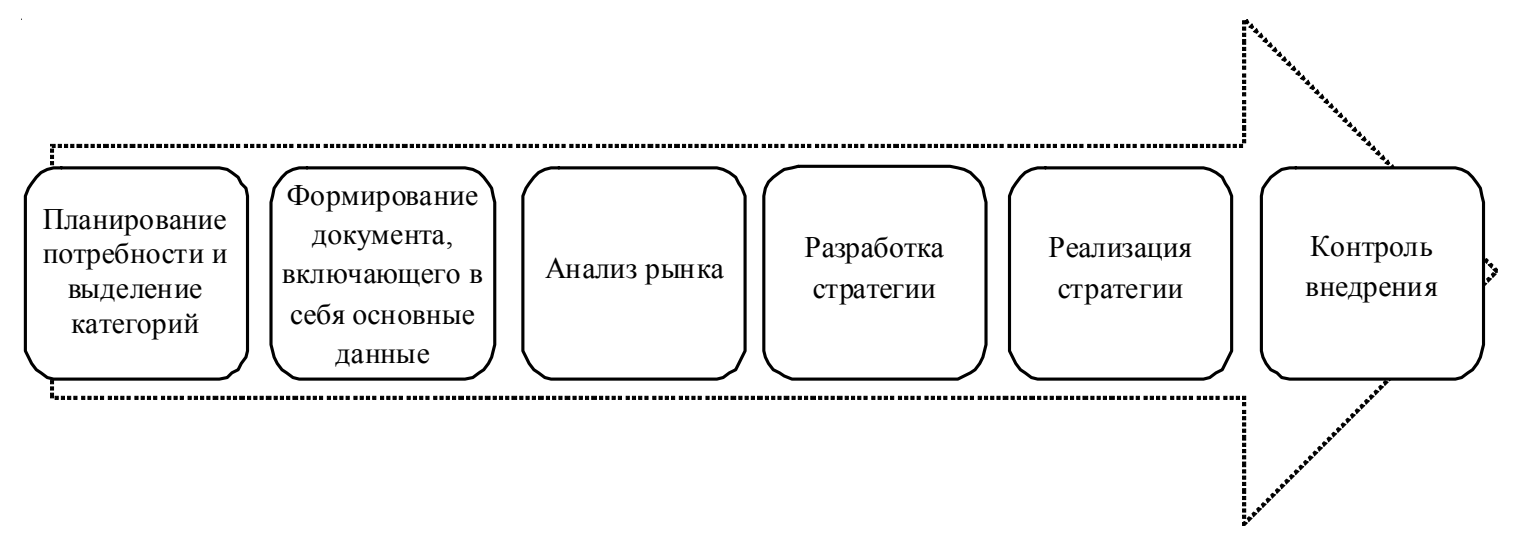

Рис. 2. Этапы создания категорийной стратегии

Примечание. Составлено авторами по: [Единые отраслевые ...]. 
Решения по консолидации закупок и возможным лотам принимается на основе матрицы изготовителей (табл. 1). Формирование матрицы изготовителей - это определение количества изготовителей / сервисных предприятий по категории и выявление наиболее / наименее конкурентной номенклатуры. С целью увеличения силы спроса потребность целесообразно объединять для проведения единой закупки при соблюдении всех нижеследующих критериев:

a) ассортимент каждого изготовителя (сервисного предприятия) составляет $100 \%$ стоимости объединенной закупки;

б) на каждую позицию товара (работы или услуги) имеется не менее 3 изготовителей (сервисных предприятий).

\section{3. Анализ рынка.}

Основная цель - сбор и анализ данных о рынке поставщиков, что позволяет учесть максимальную конкуренцию между поставщиками и минимальные цены закупки; понимание тенденций на рынке, что обеспечивает возможность выбора наиболее оптимальной закупки (условия закупки сопутствующих материалов, оборудования, гарантии, условия оплаты, возможности снижения стоимости и др.).

Анализ рынка проводится в разрезе каждого лота и состоит из следующих этапов: 1) сбор и анализ данных по рынку изготовителей / сервисных предприятий; 2) анализ структуры потребности на рынке; 3 ) анализ ценовых предложений на номенклатуру товаров, работ или услуг.

Данный шаг позволяет в дальнейшем определить силу предложения и спроса на мат- рице спроса и предложений, а также получить информацию о ценовых котировках рынка.

4. Разработка стратегии.

Основная цель - формулирование категорийной стратегии для определения наиболее оптимального подхода к закупке, который обеспечит выполнение целей в части снижения затрат на закупку товара, работ или услуг.

5. Реализация стратегии.

Основная цель - выполнение утвержденного плана-графика реализации инициатив в рамках категорийной стратегии.

Реализация стратегии содержит следующие этапы: 1) разработка детального планаграфика; 2) выполнение плана-графика; 3) отчетность.

6. Контроль внедрения.

Основной целью является контроль результатов внедрения категорийной стратегии и эффективности управления категорией товаров, работ или услуг.

Контроль внедрения состоит из следующих этапов: 1) анализ реализации стратегии; 2) анализ результатов категорийного управления. Фактический эффект от реализации категорийной стратегии рассчитывается как с учетом, так и без учета инфляции.

Одним из основных и важных этапов при выборе категорийной стратегии является анализ тенденций рынка. Необходимо оценить силу спроса организации (см. табл. 2) и силу предложения поставщиков (см. табл. 3) по пятибалльной шкале.

Для оценки спроса используются данные по структуре потребности на рынке, получен-

\section{Пример формирования лотов на основе матрицы изготовителей}

Таблица 1

\begin{tabular}{|c|l|c|c|c|c|c|c|c|c|c|}
\hline $\begin{array}{c}\text { № } \\
\text { лота }\end{array}$ & \multicolumn{1}{|c|}{$\begin{array}{c}\text { Наименование } \\
\text { предмета закупки }\end{array}$} & $\begin{array}{c}\text { Кол-во, } \\
\text { шт. }\end{array}$ & $\begin{array}{c}\text { Дата начала } \\
\text { поставки }\end{array}$ & $\begin{array}{c}\text { Сумма, } \\
\text { руб. }\end{array}$ & $\Pi$ * 1 & П 2 & П 3 & П 4 & П 5 & П 6 \\
\hline 1 & Клапан регулирующий & 2 & 01.12 .19 & 11640000 & 1 & 1 & 1 & & & \\
\hline 1 & Клапан регулирующий & 2 & 01.12 .19 & 10640000 & 1 & 1 & 1 & & & \\
\hline 2 & $\begin{array}{l}\text { Клапаны регулирующие } \\
\text { типа СКА }\end{array}$ & 8 & 01.10 .19 & 60090000 & & & 1 & 1 & 1 & \\
\hline 3 & $\begin{array}{l}\text { Клапаны КОСМ с серво- } \\
\text { приводом }\end{array}$ & 4 & 01.07 .20 & 97230000 & & 1 & & 1 & & 1 \\
\hline 1 & $\begin{array}{l}\text { Клапан запорно-дроссель- } \\
\text { ный }\end{array}$ & 2 & 01.12 .19 & 18350120 & 1 & 1 & 1 & & & \\
\hline 2 & $\begin{array}{l}\text { Клапан регулирующий } \\
\text { СКА 024.200 }\end{array}$ & 4 & 01.11 .19 & 13270000 & & & 1 & 1 & 1 & \\
\hline
\end{tabular}

Примечание. Составлено авторами. * - поставщик / изготовитель. 
О.Ю. Кириллова, О.В. Ланцова. Повышение эффективности закупок

Таблица 2

Критерии оценки силы спроса

\begin{tabular}{|c|l|l|}
\hline $\begin{array}{c}\text { № } \\
\text { п/п }\end{array}$ & \multicolumn{1}{|c|}{ Критерий } & \multicolumn{1}{|c|}{ Комментарий } \\
\hline 1 & $\begin{array}{l}\text { Доля на рынке / доля в продажах } \\
\text { ключевых поставщиков }\end{array}$ & $\begin{array}{l}\text { Отношение потребности организации к общей потребности на } \\
\text { рынке целевой категории или к объему продаж ключевых по- } \\
\text { ставщиков при олигопольном рынке }\end{array}$ \\
\hline 2 & $\begin{array}{l}\text { Перспективы роста и развития для } \\
\text { поставщиков }\end{array}$ & $\begin{array}{l}\text { Перспективы увеличения спроса организации на продукцию, } \\
\text { работы или услуги целевой категории }\end{array}$ \\
\hline 3 & $\begin{array}{l}\text { Перспективы развития квалификации } \\
\text { для поставщиков }\end{array}$ & Возможность расширения номенклатуры для поставщика \\
\hline 4 & Перспективы работы с организацией & $\begin{array}{l}\text { Дополнительное увеличение силы спроса может дать пре- } \\
\text { стижность работы с организацией }\end{array}$ \\
\hline
\end{tabular}

Примечание. Составлено авторами.

Таблича 3

Критерии оценки силы предложения

\begin{tabular}{|c|l|l|}
\hline $\begin{array}{c}\text { № } \\
\text { п/п }\end{array}$ & \multicolumn{1}{|c|}{ Критерий } & \multicolumn{1}{|c|}{ Комментарий } \\
\hline 1 & Количество поставщиков на рынке & $\begin{array}{l}\text { Чем больше изготовителей однотипной продукции на рынке, тем } \\
\text { ниже сила предложения }\end{array}$ \\
\hline 2 & $\begin{array}{l}\text { Степень фрагментированности } \\
\text { рынка }\end{array}$ & $\begin{array}{l}\text { Чем выше совокупная доля рынка у ведущих нескольких изготови- } \\
\text { телей, тем выше сила предложения }\end{array}$ \\
\hline 3 & Динамика консолидации & $\begin{array}{l}\text { Если на рынке есть тренд консолидации изготовителей, это повы- } \\
\text { шает силу предложения }\end{array}$ \\
\hline 4 & $\begin{array}{l}\text { Барьеры для входа на рынок новых } \\
\text { поставщиков }\end{array}$ & $\begin{array}{l}\text { Возможность входа на рынок новых изготовителей (необходимые } \\
\text { инвестиции, сопротивление существующих изготовителей, барьеры } \\
\text { государственного регулирования и т. д.) }\end{array}$ \\
\hline 5 & $\begin{array}{l}\text { Легкость замены поставщика } \\
\text { Возможность замены текущего поставщика-изготовителя другими } \\
\text { эффективными изготовителями }\end{array}$ \\
\hline 6 & $\begin{array}{l}\text { Барьеры для входа на рынок про- } \\
\text { дуктов-заменителей и продуктов- } \\
\text { аналогов }\end{array}$ & $\begin{array}{l}\text { Возможность вывода на рынок новых товаров (инвестиции в раз- } \\
\text { работку, маркетинг) }\end{array}$ \\
\hline 7 & Доступность продукции на рынке & Чем легче приобретение продукции, тем ниже сила предложения \\
\hline
\end{tabular}

Примечание. Составлено авторами.

ные в результате текущего исследования. Для оценки силы предложения - данные по рынку изготовителей / сервисных предприятий, полученные в результате исследования.

Далее для получения результирующего балла необходимо разделить сумму баллов на количество показателей и отметить балл по силе спроса и предложения на горизонтальной и вертикальной осях матрицы спроса и предложения соответственно, после чего на графике необходимо определить положение категории (точка пересечения значений силы спроса и предложения).

Категорийные стратегии могут применяться в соответствии с позицией организации на матрице сил спроса и предложения (см. рис. 3). Матрица является основным инструментом выбора одной из четырех стратегий для категории.
Расчет ожидаемого эффекта от реализации стратегии происходит путем сравнения стоимости предыдущих и предстоящих закупок по категории и как с учетом, так и без учета инфляции.

Ожидаемый эффект без учета инфляции рассчитывается по формуле

$$
S_{\text {кат }}=\sum\left(P_{i}^{0}-\mathrm{HM}_{i}^{1}\right) * Q_{i}^{1} ; i=1 \ldots n,
$$

Ожидаемый эффект с учетом инфляции рассчитывается по формуле

$$
S I_{\text {кат }}=\sum\left(P_{i}^{0} * K_{m}^{0}-\mathrm{HM}_{i}^{1}\right) * Q_{i}^{1} ; i=1 \ldots n,
$$

где $P_{i}^{0}-$ стоимость последней закупки $i$-й позиции товаров (единичной расценки на работы или услуги) в базовом периоде; НМЦ 1 - начальная максимальная цена $i$-й позиции товаров (единичной рас- 


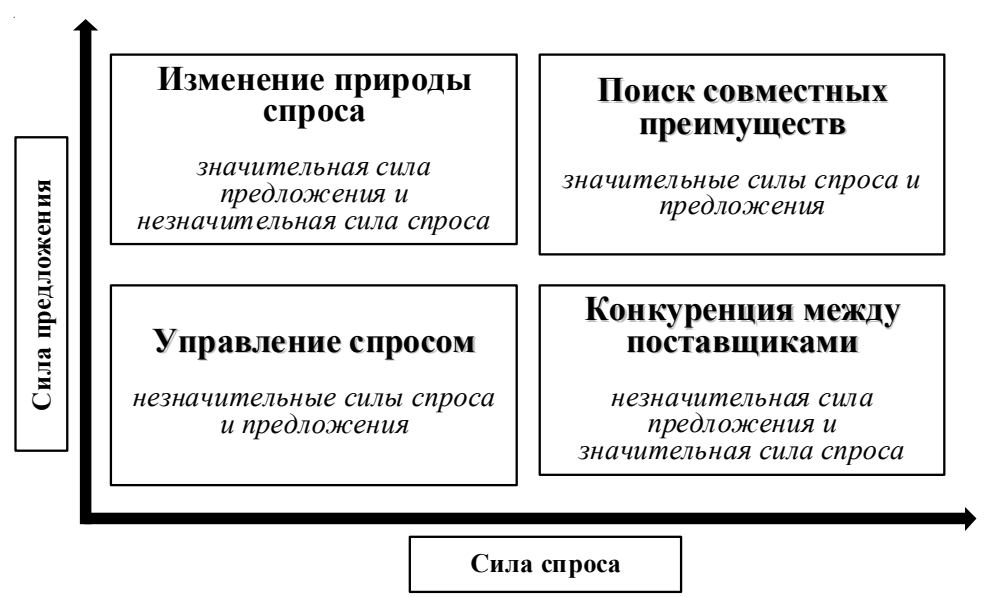

Рис. 3. Базовые категорийные стратегии

Примечание. Составлено авторами.

ценки на работы / услуги) в текущем периоде; $Q_{i}^{1}-$ планируемое количество закупки $i$-й позиции в текущем периоде; $i$ - число позиций категории, закупавшихся ранее; $K_{m}^{0}$ - индекс цен (согласно данным Госкомстата) на позиции категории от базового до текущего периода. При отсутствии индекса цен по анализируемой категории в базе Госкомстата в расчетах применяется индекс цен по промышленности от базового до текущего периода.

Для последующего определения относительного эффекта по категории рассчитывается база для анализа эффекта по формуле

$$
\mathrm{AB}_{\text {кат }}=\sum P_{i}^{0} * Q_{i}^{1} ; i=1 \ldots n .
$$

Расчет эффекта делается в разрезе каждой позиции закупки, в расчете указываются: реквизиты предыдущего договора; поставщик по предыдущему договору; условия оплаты по предыдущему договору; стоимость позиций по предыдущему договору; начальная максимальная цена (далее - НМЦ) позиции на текущий период.

Фактический эффект от реализации категорийной стратегии также рассчитывается как с учетом, так и без учета инфляции.

Фактический эффект без учета инфляции рассчитывается по формуле

$$
S_{\text {кат }}=\sum\left(P_{i}^{0}-\mathrm{HM}_{i}^{1}\right) * Q_{i}^{1} ; i=1 \ldots n,
$$

Фактический эффект с учетом инфляции рассчитывается по формуле

$$
S I_{\text {кат }}=\sum\left(P_{i}^{0} * K_{m}^{0}-\mathrm{HM}_{i}^{1}\right) * Q_{i}^{1} ; i=1 \ldots n,
$$

где $P_{i}^{0}$ - стоимость закупки $i$-й позиции товаров (единичной расценки на работы или услуги) в базовом периоде; $P_{i}^{1}$ - стоимость закупки $i$-й позиции товаров (единичной расценки на работы или услуги) в текущем периоде; $Q_{i}^{1}$ - фактическое количество закупки $i$-й позиции в текущем периоде; $i$ - число позиций категории, закупавшихся ранее; $K_{m}^{0}-$ индекс цен (согласно данным Госкомстата) на позиции категории от базового до текущего периода. При отсутствии индекса цен по анализируемой категории в базе Госкомстата в расчетах применяется индекс цен по промышленности от базового до текущего периода.

Расчет фактического эффекта прикладывается к стратегии, результаты расчета вносятся в пояснительную записку [Приказ от 05.06.2017 № 9_719-П ...].

\section{Результаты и обсуждение}

Рассмотрим проведенную централизованную закупку «Средства автотранспортные».

Централизованная закупка - это закупка в двух и более дивизионах / организациях корпорации одноименной номенклатуры [Приказ от 05.06.2017 № 9_719-П ...].

Для начала категорийным менеджером проводился сбор информации на предмет объединения потребности в предмете закупки (автотранспорт) на всех АЭС, также была проанализирована история предыдущих закупок за три года для поиска цен.

По результатам этого этапа для 6 АЭС определилась потребность по одинаковым категориям: 
1) автомобили легковые;

2) средства автотранспортные для перевозки 10 или более человек;

3) средства автотранспортные грузовые;

4) средства автотранспортные специального назначения.

По результатам анализа прошлых закупок были найдены цены за единицу продукции по заключенным ранее договорам закупок (за шт.):

- легковой автомобиль: 1796 491,721 руб. с НДС;

- автобусы пригородные: 2871 858,806 руб. с НДС;

- автомобили для перевозки грузов: 1376 576,887 руб. с НДС;

- специальные автомобили для перевозки грузов: 4609 936,267 руб. с НДС.

Далее для составления матрицы изготовителей были проанализированы более 10 потенциальных поставщиков, получены от них технико-коммерческие предложения, после чего проводился анализ тенденций на рынке. Оценки сил спроса и предложения показаны в таблицах 4 и 5 соответственно.

После расчета средних баллов по силам, приведенным выше, получаем стратегию «Управление спросом» (рис. 4).

Следующим этапом стало проведение конкурентной процедуры и переторжек для снижения цены, проведение преддоговорных переговоров с победителем и заключение договора.

В сводную таблицу 6 внесены данные о предмете закупки в требуемом количестве, базовая цена (стоимость закупки по ценам прошлых закупок), а также текущие цены закупки.

Эффект закупки рассчитан в абсолютном значении и в относительном, а также с учетом и без учета инфляции.

Также указан коэффициент инфляции, рассчитанный путем перемножения коэффициентов за каждый месяц в период с даты проведения прошлой закупки до даты проведения текущей исходя из данных по индексам цен производителей по видам экономической деятельности в РФ в соответствии с данными Федеральной службы государственной статистики [Федеральная служба ...].

По результатам данной централизованной закупки получен положительный эффект (экономия) за счет того, что закупка была объедине- на для нескольких филиалов дивизиона, а непроводилась отдельно для каждого, была создана стратегия закупочной процедуры по предмету закупки с подробным анализом рынка и минимизацией рисков на каждом этапе закупки.

Исходя из расчетов эффекта закупки видно, что по 3 позициям эффект положительный как с учетом инфляции, так и без ее учета. По категории «Автобусы пригородные для групповых перевозок» закупка в абсолютном значении вышла дороже, но, если учитывать инфляцию, в итоге эффект закупки положителен.

\section{Выводы}

Система государственных закупок - важный и динамично развивающийся общественный институт в России.

Концепция категорийного менеджмента (управления категориями) для компаний - это способ управления закупками, позволяющий приобретать необходимые товары эффективнее, экономить значительные суммы на закупках. Менеджеры по закупкам объединяют разрозненные потребности компании на приобретение товаров по категориям в единый контракт (и цену).

Категория - это, по сути, любая группа аналогичных товаров, которые компания хочет купить в рамках единой закупки. Часть управления касается применения методологии закупок для обеспечения максимальной экономии средств [Что такое ... , 2019].

При разработке категорийной стратегии необходимо провести качественный анализ рынка, что позволит обеспечить максимальное покрытие спроса предложением - максимальную конкуренцию между поставщиками и минимальные цены закупки; понимание тенденций на рынке, оценить власть (влияние) поставщика и покупателя на рынке и определить оптимальные закупочные стратегии.

Процесс кластеризации и централизации закупки схожих товаров в более крупный контракт, который легче администрировать и который снижает затраты, - основа управления категориями. Ключевым моментом управления категориями является упрощение спроса и заключение более крупного контракта на рынке. Чем больше масштаб, тем ниже цена за единицу товара. 
Оценка сил спроса по стратегии

\begin{tabular}{|c|c|c|c|c|c|c|c|c|}
\hline \multirow{2}{*}{ № } & \multirow{2}{*}{$\begin{array}{c}\text { Наименова- } \\
\text { ние } \\
\text { показателя }\end{array}$} & \multirow{2}{*}{ Комментарии } & \multicolumn{5}{|c|}{ Оценка (баллы) } & \multirow{2}{*}{$\begin{array}{c}\text { Оцен- } \\
\text { ка по } \\
\text { КС } \\
\end{array}$} \\
\hline & & & 1 & 2 & 3 & 4 & 5 & \\
\hline C 1 & $\begin{array}{l}\text { Доля на } \\
\text { рынке / до- } \\
\text { ля в про- } \\
\text { дажах } \\
\text { ключевых } \\
\text { изготови- } \\
\text { телей }\end{array}$ & $\begin{array}{l}\text { Определяется от- } \\
\text { ношение объема } \\
\text { потребности орга- } \\
\text { низации к общей } \\
\text { потребности на } \\
\text { рынке целевой ка- } \\
\text { тегории или к объ- } \\
\text { ёму продаж ключе- } \\
\text { вых поставщиков } \\
\text { (чем больше доля } \\
\text { потребности орга- } \\
\text { низации в общей } \\
\text { потребности на } \\
\text { рынке, тем выше } \\
\text { сила спроса) }\end{array}$ & $\begin{array}{c}\text { менее } \\
10 \%\end{array}$ & $\begin{array}{l}\text { от } 10 \% \\
\text { до } 25 \%\end{array}$ & $\begin{array}{l}\text { от } 25 \% \\
\text { до } 50 \%\end{array}$ & $\begin{array}{l}\text { от } 50 \% \\
\text { до } 75 \%\end{array}$ & $\begin{array}{l}\text { более } \\
75 \%\end{array}$ & 1 \\
\hline C 2 & $\begin{array}{l}\text { Перспек- } \\
\text { тивы роста } \\
\text { и развития } \\
\text { для изгото- } \\
\text { вителей }\end{array}$ & $\begin{array}{l}\text { Определяются пер- } \\
\text { спективы увеличе- } \\
\text { ния спроса органи- } \\
\text { зации на продукцию } \\
\text { целевой категории } \\
\text { (чем выше возмож- } \\
\text { ности роста объема } \\
\text { потребности орга- } \\
\text { низации, тем выше } \\
\text { сила спроса) }\end{array}$ & $\begin{array}{l}\text { Низкие: } \\
\text { объем } \\
\text { закупок } \\
\text { будет па- } \\
\text { дать бо- } \\
\text { лее чем } \\
\text { на } 20 \%\end{array}$ & $\begin{array}{l}\text { Ниже } \\
\text { среднего: } \\
\text { объем } \\
\text { закупок } \\
\text { будет па- } \\
\text { дать ме- } \\
\text { нее чем } \\
\text { на } 20 \%\end{array}$ & $\begin{array}{l}\text { Средние: } \\
\text { объем } \\
\text { закупок } \\
\text { будет } \\
\text { примерно } \\
\text { на преж- } \\
\text { нем } \\
\text { уровне }\end{array}$ & $\begin{array}{l}\text { Выше } \\
\text { среднего: } \\
\text { объем } \\
\text { закупок } \\
\text { вырастет } \\
\text { до уровня } \\
\text { не более } \\
\mathbf{2 0} \%\end{array}$ & $\begin{array}{l}\text { Высокие: } \\
\text { объем } \\
\text { закупок } \\
\text { вырастет } \\
\text { более } \\
\text { чем на } \\
\mathbf{2 0 \%}\end{array}$ & 3 \\
\hline C 3 & $\begin{array}{l}\text { Перспек- } \\
\text { тивы раз- } \\
\text { вития ква- } \\
\text { лификации } \\
\text { для изгото- } \\
\text { вителей }\end{array}$ & $\begin{array}{l}\text { Возможности рас- } \\
\text { ширения номенкла- } \\
\text { туры для изготови- } \\
\text { теля, взаимовыгод- } \\
\text { ное сотрудничество } \\
\text { (возможность раз- } \\
\text { вития взаимовы- } \\
\text { годного сотрудни- } \\
\text { чества с изготови- } \\
\text { телем увеличивает } \\
\text { силу спроса) }\end{array}$ & $\begin{array}{l}\text { Низкие: } \\
\text { приобре- } \\
\text { таемая } \\
\text { номенк- } \\
\text { латура } \\
\text { товаров, } \\
\text { работ, } \\
\text { услуг бу- } \\
\text { дет со- } \\
\text { кращать- } \\
\text { ся более } \\
\text { чем на } \\
\mathbf{2 0 \%}\end{array}$ & $\begin{array}{l}\text { Ниже } \\
\text { среднего: } \\
\text { приобре- } \\
\text { таемая } \\
\text { номенк- } \\
\text { латура } \\
\text { товаров, } \\
\text { работ, } \\
\text { услуг бу- } \\
\text { дет со- } \\
\text { кращать- } \\
\text { ся менее } \\
\text { чем на } \\
\mathbf{2 0} \%\end{array}$ & $\begin{array}{l}\text { Средние: } \\
\text { приобре- } \\
\text { таемая } \\
\text { номенк- } \\
\text { латура } \\
\text { товаров, } \\
\text { работ, } \\
\text { услуг бу- } \\
\text { дет при- } \\
\text { мерно на } \\
\text { прежнем } \\
\text { уровне }\end{array}$ & $\begin{array}{l}\text { Выше } \\
\text { среднего: } \\
\text { приобре- } \\
\text { таемая } \\
\text { номенк- } \\
\text { латура } \\
\text { товаров, } \\
\text { работ, ус- } \\
\text { луг будет } \\
\text { увеличи- } \\
\text { ваться не } \\
\text { более чем } \\
\text { на } 20 \%\end{array}$ & $\begin{array}{l}\text { Высокие: } \\
\text { приобре- } \\
\text { таемая } \\
\text { номенк- } \\
\text { латура } \\
\text { товаров, } \\
\text { работ, } \\
\text { услуг бу- } \\
\text { дет уве- } \\
\text { личи- } \\
\text { ваться } \\
\text { более } \\
\text { чем на } \\
\mathbf{2 0} \%\end{array}$ & 3 \\
\hline C 4 & $\begin{array}{l}\text { Престиж- } \\
\text { ность рабо- } \\
\text { ты с орга- } \\
\text { низацией } \\
\text { для изгото- } \\
\text { вителя }\end{array}$ & $\begin{array}{l}\text { Дополнительное } \\
\text { увеличение силы } \\
\text { спроса может дать } \\
\text { престижность рабо- } \\
\text { ты с организацией }\end{array}$ & $\begin{array}{l}\text { Репута- } \\
\text { ционные } \\
\text { риски }\end{array}$ & $\begin{array}{l}\text { Непре- } \\
\text { стижно }\end{array}$ & $\begin{array}{l}50 / 50 . \\
\text { Отрасле- } \\
\text { вые мо- } \\
\text { нополи- } \\
\text { сты }\end{array}$ & $\begin{array}{l}\text { Пре- } \\
\text { стижно. } \\
\text { Традици- } \\
\text { онные } \\
\text { постав- } \\
\text { щики }\end{array}$ & $\begin{array}{l}\text { Очень } \\
\text { престиж- } \\
\text { но. Но- } \\
\text { вые по- } \\
\text { ставщики }\end{array}$ & 4 \\
\hline
\end{tabular}

Примечание. Составлено авторами. 
Оценка сил предложения по стратегии

\begin{tabular}{|c|c|c|c|c|c|c|c|c|}
\hline \multirow[b]{2}{*}{ № } & \multirow{2}{*}{$\begin{array}{c}\text { Наименова- } \\
\text { ние показа- } \\
\text { теля }\end{array}$} & \multirow[b]{2}{*}{ Комментарии } & \multicolumn{5}{|c|}{ Оценка (баллы) } & \multirow{2}{*}{$\begin{array}{c}\text { Оцен- } \\
\text { ка по } \\
\text { КС }\end{array}$} \\
\hline & & & 1 & 2 & 3 & 4 & 5 & \\
\hline П1 & $\begin{array}{l}\text { Количест- } \\
\text { во изгото- } \\
\text { вителей на } \\
\text { рынке }\end{array}$ & $\begin{array}{l}\text { Чем больше изготови- } \\
\text { телей однотипной про- } \\
\text { дукции на рынке, тем } \\
\text { ниже сила предложения }\end{array}$ & более 10 & От 6 до 10 & От 3 до 5 & 2 & 1 & 3 \\
\hline$\Pi 2$ & $\begin{array}{l}\text { Степень } \\
\text { фрагмен- } \\
\text { тированно- } \\
\text { сти рынка }\end{array}$ & $\begin{array}{l}\text { Чем выше совокупная } \\
\text { доля рынка у ведущих } \\
\text { нескольких изготови- } \\
\text { телей (например, на } \\
5 \text { компаний приходится } \\
80 \% \text { рынка), тем выше } \\
\text { сила предложения }\end{array}$ & $\begin{array}{l}\text { Высокая } \\
\text { конку- } \\
\text { рентность }\end{array}$ & $\begin{array}{l}\text { Выше } \\
\text { среднего }\end{array}$ & Средняя & $\begin{array}{l}\text { Олиго- } \\
\text { полия }\end{array}$ & $\begin{array}{l}\text { Моно- } \\
\text { полия }\end{array}$ & 2 \\
\hline$\Pi 33$ & $\begin{array}{l}\text { Динамика } \\
\text { консоли- } \\
\text { дации }\end{array}$ & $\begin{array}{l}\text { Если на рынке есть } \\
\text { тренд консолидации } \\
\text { изготовителей, это по- } \\
\text { вышает силу предло- } \\
\text { жения }\end{array}$ & $\begin{array}{l}\text { Демоно- } \\
\text { полиза- } \\
\text { ция на } \\
\text { более } \\
\text { трех из- } \\
\text { готовите- } \\
\text { лей }\end{array}$ & $\begin{array}{l}\text { Демонопо- } \\
\text { лизация на } \\
\text { менее трех } \\
\text { изготови- } \\
\text { телей }\end{array}$ & $\begin{array}{l}\text { Нет яв- } \\
\text { ной ак- } \\
\text { тивности }\end{array}$ & $\begin{array}{l}\text { Консор- } \\
\text { циумы и } \\
\text { частич- } \\
\text { ное ог- } \\
\text { раниче- } \\
\text { ние } \\
\text { конку- } \\
\text { ренции }\end{array}$ & $\begin{array}{l}\text { По- } \\
\text { купка, } \\
\text { кон- } \\
\text { троль } \\
\text { над } \\
\text { дея- } \\
\text { тель- } \\
\text { ностью }\end{array}$ & 3 \\
\hline$\Pi 4$ & $\begin{array}{l}\text { Барьеры } \\
\text { для входа } \\
\text { на рынок } \\
\text { новых из- } \\
\text { готовите- } \\
\text { лей }\end{array}$ & $\begin{array}{l}\text { Оценивается возмож- } \\
\text { ность входа на рынок } \\
\text { новых изготовителей } \\
\text { (необходимые инвести- } \\
\text { ции, возможное сопро- } \\
\text { тивление существующих } \\
\text { изготовителей, государ- } \\
\text { ственное регулирование } \\
\text { и т. д.). При наличии } \\
\text { существенных барьеров } \\
\text { на вход сила предложе- } \\
\text { ния увеличивается }\end{array}$ & Низкие & $\begin{array}{l}\text { Ниже } \\
\text { среднего }\end{array}$ & Средние & $\begin{array}{l}\text { Выше } \\
\text { среднего }\end{array}$ & $\begin{array}{l}\text { Высо- } \\
\text { кие }\end{array}$ & 3 \\
\hline$\Pi 5$ & $\begin{array}{l}\text { Легкость } \\
\text { замены по- } \\
\text { ставщика- } \\
\text { изготови- } \\
\text { теля }\end{array}$ & $\begin{array}{l}\text { Оценивается возмож- } \\
\text { ность замены текущего } \\
\text { поставщика-изготови- } \\
\text { теля организации дру- } \\
\text { гими эффективными } \\
\text { изготовителями. Чем } \\
\text { легче можно сменить } \\
\text { текущего поставщика, } \\
\text { тем ниже сила предло- } \\
\text { жения }\end{array}$ & Высокая & $\begin{array}{l}\text { Выше } \\
\text { среднего }\end{array}$ & Средняя & $\begin{array}{l}\text { Ниже } \\
\text { среднего }\end{array}$ & Низкая & 3 \\
\hline П 6 & $\begin{array}{l}\text { Барьеры } \\
\text { для входа } \\
\text { на рынок } \\
\text { продуктов- } \\
\text { замените- } \\
\text { лей и про- } \\
\text { дуктов- } \\
\text { аналогов }\end{array}$ & $\begin{array}{l}\text { Оценивается возмож- } \\
\text { ность вывода на рынок } \\
\text { новых товаров (необ- } \\
\text { ходимые инвестиции в } \\
\text { разработку и марке- } \\
\text { тинг, государственное } \\
\text { регулирование и т. д.). } \\
\text { При наличии сущест- } \\
\text { венных барьеров на } \\
\text { вход сила предложения } \\
\text { увеличивается }\end{array}$ & Низкие & $\begin{array}{l}\text { Ниже } \\
\text { среднего }\end{array}$ & Средние & $\begin{array}{l}\text { Выше } \\
\text { среднего }\end{array}$ & $\begin{array}{l}\text { Высо- } \\
\text { кие }\end{array}$ & 2 \\
\hline$\Pi 7$ & $\begin{array}{l}\text { Доступ- } \\
\text { ность про- } \\
\text { дукции на } \\
\text { рынке }\end{array}$ & $\begin{array}{l}\text { Чем легче приобрете- } \\
\text { ние продукции, тем } \\
\text { ниже сила предложе- } \\
\text { ния }\end{array}$ & Высокая & $\begin{array}{l}\text { Выше } \\
\text { среднего }\end{array}$ & Средняя & $\begin{array}{l}\text { Ниже } \\
\text { среднего }\end{array}$ & Низкая & 3 \\
\hline
\end{tabular}

Примечание. Составлено авторами. 


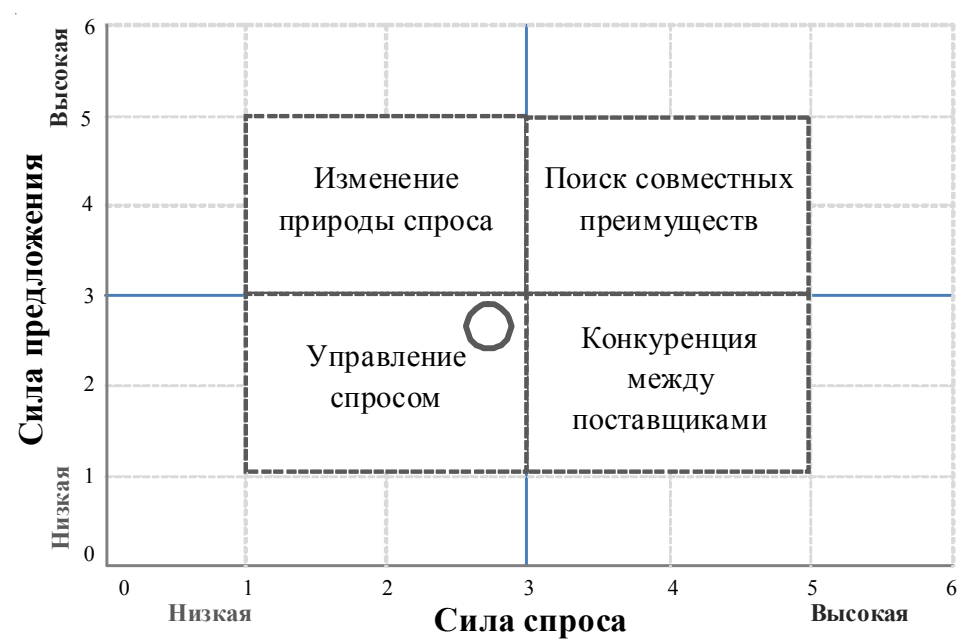

Рис. 4. Матрица выбора базовой группы стратегий

Таблииа 6

\section{Сводная таблица}

\begin{tabular}{|c|c|c|c|c|c|c|}
\hline $\begin{array}{l}\text { № } \\
\text { п/п }\end{array}$ & $\begin{array}{c}\text { Наименование МТРиО, } \\
\text { работ, услуг к закупке }\end{array}$ & $\begin{array}{l}\text { Кол-во, } \\
\text { шт. }\end{array}$ & $\begin{array}{c}\text { Коэффи- } \\
\text { циент } \\
\text { инфляции }\end{array}$ & $\begin{array}{c}\text { Цена за ед. } \\
\text { в базовом пе- } \\
\text { риоде, руб. с } \\
\text { НДС }\end{array}$ & $\begin{array}{c}\text { База для анализа } \\
\text { эффекта, руб. с } \\
\text { НдС }\end{array}$ & $\begin{array}{c}\text { Цена за ед. в те- } \\
\text { кущем периоде } \\
\text { (НМЦ), руб. с } \\
\text { НДС }\end{array}$ \\
\hline 1 & Легковой автомобиль & 2 & 1,050 & 1796491,721 & 3592983,442 & 1659766,665 \\
\hline 2 & $\begin{array}{l}\text { Автобусы пригородные } \\
\text { для групповых перевозок }\end{array}$ & 4 & 1,176 & 2871858,806 & 11487435,225 & 3015000,000 \\
\hline 3 & $\begin{array}{l}\text { Автомобили для пере- } \\
\text { возки грузов }\end{array}$ & 1 & 1,019 & 1376576,887 & 1376576,887 & 1357812,810 \\
\hline 4 & $\begin{array}{l}\text { Специальные автомоби- } \\
\text { ли для перевозки грузов }\end{array}$ & 1 & 1,205 & 4609936,267 & 4609936,267 & 4515000,000 \\
\hline & Итог по КС & 8 & - & 10654863,681 & 21066931,821 & 10547579,475 \\
\hline
\end{tabular}

Окончание таблицы 6

\begin{tabular}{|c|l|c|c|c|c|}
\hline $\begin{array}{c}\text { № } \\
\text { п/п }\end{array}$ & $\begin{array}{c}\text { Наименование МТРиО, } \\
\text { работ, услуг к закупке }\end{array}$ & $\begin{array}{c}\text { Эффект без учета } \\
\text { инфляции, руб. с } \\
\text { НДС }\end{array}$ & $\begin{array}{c}\text { Эффект с учетом } \\
\text { инфляции, руб. } \\
\text { с НДС }\end{array}$ & $\begin{array}{c}\text { Эффект относи- } \\
\text { тельный без учета } \\
\text { инфляции, \% }\end{array}$ & $\begin{array}{c}\text { Эффект относи- } \\
\text { тельный с учетом } \\
\text { инфляции, \% }\end{array}$ \\
\hline 1 & Легковой автомобиль & 273450,112 & 453566,552 & 7,611 & 12,624 \\
\hline 2 & $\begin{array}{l}\text { Автобусы пригородные } \\
\text { для групповых перевозок }\end{array}$ & $-572564,775$ & 1451794,668 & $-4,984$ & 12,638 \\
\hline 3 & $\begin{array}{l}\text { Автомобили для пере- } \\
\text { возки грузов }\end{array}$ & 18764,077 & 45228,686 & 1,363 & 3,286 \\
\hline 4 & $\begin{array}{l}\text { Специальные автомоби- } \\
\text { ли для перевозки грузов }\end{array}$ & 94936,267 & 1039621,264 & 2,059 & 22,552 \\
\hline \multicolumn{7}{|r|}{ Итог по KC } & $-185414,319$ & 2990211,170 & 6,049 & 51,100 \\
\hline
\end{tabular}

Управление категорией как самостоятельной бизнес-единицей позволяет достичь сокращения затрат по всей цепи поставок, повышения надежности, ритмичности в целях увеличения экономического эффекта за счет высокой оборачиваемости, сокращения товарных запасов и улучшения сервиса закупок.

\section{СПИСОК ЛИТЕРАТУРЫ}

Вавилина, А. В. Классическая модель категорийного менеджмента и этапы ее внедрения / А. В. Вавилина, О. С. Горлова // Материалы VI, VII Международной научно-практической конференции «Экономика и современный менеджмент». - M. : CHRONOS, 2016. - C. 16-24. 
Единые отраслевые методические рекомендации по управлению категориями МТРиО, работ, услуг : приказ Концерна от 21.05.2015 № 9/522-П. - Не опубл.

Ломтев, А. П. Управление бизнесом. Категорийный менеджмент в закупках как инструмент повышения эффективности снабжения / А. П. Ломтев // Мир климата. - Электрон. текстовые дан. - Режим доступа: https://www.hvacschool.ru/vestnik_ano/vestnik_ukc_48/ kategoriinii_menedzhment_v_zakupkah/ (дата обращения: 21.05.2019). - Загл. с экрана.

От стратегии к тактике: как категорийный менеджмент помогает экономить деньги акционеров. - Электрон. текстовые дан. - Режим доступа: http:/www.up-pro.ru/library/logistics/ procurement/kategorijnyj-management.html (дата обращения 11.05.2019). - Загл. с экрана.

Приказ от 18.11.2016 № 9_1496-П «Об утверждении и введении в действие Порядка разработки категорийных стратегий на закупку работ / услуг». - Не опубл.

Приказ от 05.06.2017 № 9_719-П «О развитии системы категорийного управления МТО». - Не опубл.

Совершенствование закупочной деятельности: чему стоит научиться предприятиям химической отрасли у лидеров в закупках. - Электрон. текстовые дан. - Режим доступа: http:// vestkhimprom.ru/posts/sovershenstvovaniezakupochnoj-deyatelnosti-chemu-stoitnauchitsya-predpriyatiyam-khimicheskojotrasli-u-liderov-v-zakupkakh (дата обращения: 14.05.2019). - Загл. с экрана.

Федеральная служба государственной статистики. Электрон. текстовые дан. - Режим доступа: http://www.gks.ru/dbscripts/cbsd/dbinet.cgi (дата обращения: 14.05.2019). - Загл. с экрана.

Что такое категорийный менеджмент в закупках? Электрон. текстовые дан. - Режим доступа: http://www.appminfo.ru/stati/news_post/chtotakoye-kategoriynyy-menedzhment-v-zakupkakh (дата обращения: 15.06.2019). - Загл. с экрана.

\section{REFERENCES}

Vavilina A.V., Gorlova O.S. Klassicheskaya model kategoriynogo menedzhmenta i etapy ee vnedreniya [Classical Model of Category Management and the Stages of Its Implementation]. Materialy VI, VII Mezhdunarodnoy nauchno-prakticheskoy konferentsii "Ekonomika $i$ sovremennyy menedzhment» [Proceedings of the $6^{\text {th }}, 7^{\text {th }}$ International Scientific and Practical Conference
"Economics and Modern Management"]. Moscow, CHRONOS Publ., 2016, pp. 16-24.

Edinye otraslevye metodicheskie rekomendatsii po upravleniyu kategoriyami MTRiO, rabot, uslug : prikaz Kontserna ot 21.05.2015 № 9/522-P [Uniform Industry Guidelines for Category Management of Materials and Equipment, Works, Services. Order of the Group of May 21, 2015 no. 9/ 522-П].

Lomtev A.P. Upravlenie biznesom. Kategoriynyy menedzhment $\mathrm{v}$ zakupkakh kak instrument povysheniya effektivnosti snabzheniya [Managing the Business. Category Management in Procurement as a Tool to Improve the Effectiveness of Supply]. Mir klimata. URL: https://www.hvacschool.ru/vestnik_ano/vestnik_ukc_48/ kategoriinii_menedzhment_v_zakupkah/(accessed 21 May 2019).

Ot strategii k taktike: kak kategoriynyy menedzhment pomogaet ekonomit dengi aktsionerov [From Strategy to Tactics. How Category Management Helps to Save Shareholders' Money]. URL: http:// www.up-pro.ru/library/logistics /procurement/ kategorijnyj-management.html (accessed 11 May 2019).

Prikaz ot 18.11.2016 № 9 1496-P «Ob utverzhdenii $i$ vvedenii $v$ deystvie Poryadka razrabotki kategoriynykh strategiy na zakupku rabot / uslug» [Order of November 18, 2016 no. 9_1496-P "On Approving and Introducing the Procedure for the Developing Categorical Strategies for Purchasing Works /Services"].

Prikaz ot 05.06.2017 № 9_719-P «O razvitii sistemy kategoriynogo upravleniya MTO»[Order of June 5, 2017 no. 9_719-П “On Developing the Category Management System of Equipment and Material Procurement"].

Sovershenstvovanie zakupochnoy deyatelnosti: chemu stoit nauchitsya predpriyatiyam khimicheskoy otrasli u liderov $v$ zakupkakh [Improvement of Procurement Activities: What Should Chemical Industry Enterprises Learn from Leaders in Procurement]. URL: http:// vestkhimprom.ru/posts/ sovershenstvovaniezakupochnoj-deyatelnosti-chemu-stoitnauchitsya-predpriyatiyam-khimicheskoj-otrasliu-liderov-v-zakupkakh (accessed 14 May 2019).

Federalnaya sluzhba gosudarstvennoy statistiki [Federal State Statistics Service]. URL: http:// www.gks.ru/dbscripts/cbsd/dbinet.cgi (accessed 14 May 2019).

Chto takoe kategoriynyy menedzhment v zakupkakh? [What is Category Management in Procurement?]. URL: http://www.appminfo.ru/stati/news_post/ chto-takoye-kategoriynyy-menedzhment-vzakupkakh (accessed 15 June 2019). 


\section{УПРАВЛЕНИЕ ЭКОНОМИЧЕСКИМ РАЗВИТИЕМ}

\section{Information about the Authors}

Oksana Yu. Kirillova, Doctor of Sciences (Economics), Associate Professor, Specialized Department of Federal Antitrust Authority of Russia, Plekhanov Russian University of Economics (RUE), Stremyannyy Lane, 36, 117997 Moscow, Russian Federation, cg_123@mail.ru, https://orcid.org/0000-0001-5135-9935

Olga V. Lantsova, Chief Specialist, Category Management Department, JSC "Concern Rosenergoatom", Kholodilnyy Lane, 3a, 115191 Moscow, Russian Federation; Master Student, Plekhanov Russian University of Economics, Stremyannyy Lane, 36, 117997 Moscow, Russian Federation, 1-o-v96@mail.ru, https://orcid.org/0000-0002-3545-2109

\section{Информация об авторах}

Оксана Юрьевна Кириллова, доктор экономических наук, доцент Базовой кафедры Федеральной антимонопольной службы России, Российский экономический университет им. Г.В. Плеханова, пер. Стремянный, 36, 117997, г. Москва, Российская Федерация, cg_123@mail.ru, https://orcid.org/0000-0001-5135-9935

Ольга Валерьевна Ланцова, главный специалист отдела категорийного менеджмента, АО «Концерн Росэнергоатом», Холодильный пер., За, 115191 г. Москва, Российская Федерация; магистрант, Российский экономический университет им. Г.В. Плеханова, пер. Стремянный, 36, 117997 г. Москва, Российская Федерация, 1-o-v-96@mail.ru, https://orcid.org/0000-0002-3545-2109 